\title{
Optimal Portfolio Allocations For Global Bank Stocks In Local Currencies And Us Dollars 1992-2001
}

Rae Weston (E-mail: rweston@1aurel.ocs.mq.edu.au), Macquarie University Guy Ford (E-mail: guy.ford@mq.edu.au), Macquarie University

\begin{abstract}
In this paper we examine the optimal composition of global portfolios of bank stocks, expressed in both local currencies and in US dollar terms, over the period January 1992 to June 2001. We estimate optimal global bank stock portfolios using two covariance optimisation algorithms - the Markowitz expected return/variance algorithm (MPT), and the Elton, Gruber and Padberg average correlation algorithm (EGP) - and compare the composition and performance of these portfolios with a portfolio comprising equally-weighted bank stocks. Our study also includes measures of skewness and kurtosis, and risk adjusted return measures based on variance, semivariance and portfolio betas. The purpose of our study is twofold. First, we wish to examine whether the covariance optimisation approaches produce significantly different portfolio allocations over the period of the study. Second, we wish to determine if the two significant events for the global banking sector in this period- the implementation of global risk-based capital adequacy standards in 1992 and the Asian banking crisis of 1997 - may have had any influence on the optimal allocation of global bank stocks in an investment portfolio. To achieve this we construct the optimal bank portfolios, using both optimisation algorithms, for the period 19921996 and 1997-2001. We include bank stock returns for 26 countries in the study. We find that the MPT and EGP optimisation algorithms do produce different portfolio allocations during both periods of the study. If return is measured against variance, the MPT algorithm produces the best performing portfolio. However if return is measured against semi-variance, the results are mixed. We also find that bank portfolios performed better on a risk-adjusted basis in the period leading up to the Asian crisis of 1997. Our most interesting finding is that if the highest risk bank stocks are removed from the portfolio, the terminal wealth of the portfolio falls by around half in each period. This suggests that higher-risk bank stocks are needed to achieve sufficient diversification to 'protect' the return for a global portfolio of bank stocks.
\end{abstract}

\section{Introduction}

In this paper we examine the optimal composition of global portfolios of bank stocks, expressed both in local currencies and in US dollar terms, over the period January 1992 to June 2001. Two approaches are taken to this in the results reported below: first, it is assumed that institutions will have hedged away the currency risk involved in investing in different markets and will therefore benchmark potential investments with respect to their local currencies. Secondly, and more probably, institutions will be primarily interested in returns and risks expressed in US dollars as the standard international currency. Accordingly, we report our results in both formats. We estimate optimal global bank stock portfolios using two covariance optimisation algorithms - the Markowitz expected return/variance algorithm (MPT), and the Elton, Gruber and Padberg average correlation algorithm (EGP) - and compare the composition and performance of these portfolios with a portfolio comprising equally-weighted bank 
stocks. Our study also includes measures of skewness and kurtosis, and risk adjusted return measures based on variance, semi-variance and portfolio betas.

The purpose of our study is twofold. First, we wish to examine whether the covariance optimisation approaches produce significantly different portfolio allocations over the period of the study. Second, we wish to determine if two significant events for the global banking sector - the implementation of global risk-based capital adequacy standards in 1992 and the Asian banking crisis of 1997 - may have had any influence on the optimal allocation of global bank stocks in an investment portfolio. To achieve this we construct the optimal bank portfolios, using both optimisation algorithms, for the period 1992-1996 and 1997-2001. We include bank stock returns for 26 countries in the study.

The paper is structured as follows. In the next section we provide a background to the study and outline the study methodology. This is followed by discussion of the results. The final section concludes with a discussion of the implications of the results.

\section{Background and Methodology}

In 1988 the Basel Committee on Banking Supervision introduced a capital measurement system for banks (commonly referred to as the Basel Accord). The system provided for the implementation of a credit risk measurement framework with a minimum capital standard of $8 \%$ of risk-weighted assets (on balance sheet and off balance sheet equivalents) by the end of 1992. Since 1988, the framework has been progressively introduced not only in member countries of the Basel Committee, but also in virtually all countries with active international banks (although they are not required to do so by any formal international agreement). A survey conducted on 129 countries participating in the ninth International Conference on Banking Supervision in Stockholm showed that in 1996 more than 90 percent of the 129 countries applied risk-weighted capital adequacy requirements in keeping with the Basel Accord (Padoa-Schioppa, (1996)). The 1988 Basel Accord mandated banks hold higher percentages of equity capital as the perceived credit risk of assets increased. Specifically, the dollar value of assets are weighted relative to risk, with higher risk credits receiving larger risk weights. ${ }^{1}$ This framework was intended to make regulatory capital more sensitive to differences in the risk profiles among banking organisations, and to lower the disincentives to hold lower risk assets inherent in a fixed ratio of capital to assets.

There has been considerable debate over incentives for banks to alter the risk profile of their assets under the Basel Accord. One school of thought asserts that capital requirements with differentiated risk weights provide an incentive for banks to shift from high-risk to low-risk assets if, for less-risky assets, the gain associated with the lower capital charge more than offsets the lower yield on these assets. Thakor (1996) and Passmore and Sharpe (1994) demonstrate that an increase in a risk-based capital requirement can cause a bank to shift from loans to less risky securities. Furlong and Keeley (1989) argue that a value-maximising bank will not increase its asset risk under more stringent capital requirements. Furfine (2000) shows that a shift in bank asset portfolios in the United States occurred following the passing of the Accord. Banks simultaneously reduced their investment in riskier commercial lending in favour of less-risky government securities, such that the share of total bank credit in commercial and industrial loans fell from $23 \%$ in 1989 to under $16 \%$ in 1994, while at the same time the share of total bank credit invested in US government securities increased from $15 \%$ to $25 \%$ over the same period. ${ }^{2}$

A second school of thought hypothesises that the risk-based capital requirements associated with the 1988 Basel Accord will result in an increase in bank risk-taking if capital requirements do not adequately reflect the relative riskiness of assets and information on the quality of the specific assets is asymmetric between regulators and ratings agencies on the one hand, and bank loan managers on the other. The basis of this hypothesis is that any

${ }^{1}$ See Bank for International Settlements (1988), "International Convergence of Capital Measurement and Capital Standards", Basel Committee publications No.4, July.

2 Furfine (2000), 1-2. Furfine points out that while the trend has partially been reversed since 1994, bank portfolios remain much less invested in commercial loans than they have over the past 25 years. 
category of assets that bears the same proportional capital charge will induce banks to shift towards more risky assets in the category. This arises because banks can earn a higher return on riskier assets within the category because higher earnings on these assets are not offset by a compensating increase in capital. If information on the quality of assets within a given category is not transparent to external parties such as ratings agencies, banks may be able to increase the risk profile of the asset book relatively unchecked. Koehn and Santomero (1980) and Kim and Santomero (1988) show that asset substitution of this form is possible within a portfolio model. The Basel Committee of Banking Supervision has itself recognised that the failure to differentiate sufficiently between credit risks within some asset categories has resulted in the practise of banks shifting their asset portfolios towards lower quality credits: "in this case, the bank's total risk-weighted assets and regulatory capital ratios would appear unchanged, even as its overall riskiness increased." ${ }^{3}$ The Basel Committee has identified a number of forms of regulatory arbitrage, all of which allow divergences to arise between a portfolio's true economic risks and the Accord's measure of risk, and this in part has instigated recent refinements to the Basel capital adequacy framework.

Empirical evidence on the relationship between bank capital requirements and bank risk-taking is mixed. Sheldon (1996) finds that US bank asset volatility rose between 1987 and 1994 and this occurred in banks that increased their capital ratios and those that did not. However, in the case of Japanese banks, higher capital ratios tended to be matched by lower asset volatility. Gennotte and Pyle (1991) find that risk-taking in banks increases when capital requirements are increased. Calem and Rob (1999) quantify the effect of capital-based regulation on a cross section of US banks using banking sector data for 1984-1993. They find a U-shaped relationship between capital position and risk-taking: undercapitalised banks take maximum risk and as a bank's capital rises they take less risk. However, as capital continues to rise, they find that a bank will take on more risk again. They find that severely undercapitalised banks take higher risks because costs of bankruptcy are shifted to the deposit insurance fund in the United States. Well-capitalised banks take higher risks because of their higher profitability and low probability of bankruptcy. These mixed empirical findings may, in part, be a product of the difficulties encountered in measuring risk in bank assets with data that is publicly available.

Juxtaposed against this the implementation of risk-based capital adequacy standards is the apparent buildup in credit risks in the banking books in the Asian countries, which manifested in the so-called Asian financial crisis of 1997. The large loan losses on the books of Asian banks in 1997 has led some observers to conclude that bank capital standards were ineffective in controlling risk-taking by banks in the region. That is, despite banks in the region conforming to minimum capital requirements under the Basel Accord, banks appear to have been undercapitalised relative to the credit risks in their books. In a previous study, Weston and Ford (2002) examined data for the period 1992-97 to assess the potential of risk-based capital requirements on bank risk-taking in the region, as measured by volatility in bank returns. They find an improvement in the risk/return profile of banks in Australia, Canada and the United States, but deterioration in the risk/return profile of Asian banks. The latter result is perhaps not surprising given the eventual collapse of banks in the region in 1997. This lends support to the hypothesis that the Basel capital adequacy requirements did not necessarily discourage riskier lending by banks in some countries. In the Asian banking context, we concluded that a key source of problems lay in loan loss provisioning policies, bank accounting standards and loan classifications standards in the region.

One of the objectives of this paper is to assess whether these events may have had any influence on the optimal allocation of global bank stocks in an investment portfolio. To address this we construct the optimal bank portfolios, using stock returns for the banking sectors of 26 countries for the period 1992-1996 and 1997-2001. With respect to the first period, we hypothesise that banks from the Asian region would be included in the optimal portfolio because these banks would have shown high returns as accounting standards and loan classifications standards allowed them to effectively circumvented capital controls and increase the proportion of higher risk/higher return business on their books without commensurate increases in capital. Importantly, we expect that investors in Asian bank stocks during this period would have been attracted to these returns, ignorant of the fact that these banks were becoming increasingly undercapitalised relative to credit risk. In the second period of the study, we expect that few, if any, Asian banks would be included in the optimal portfolio following the high volatility in bank returns arising from bank collapses and loan write-downs in the region.

\footnotetext{
${ }^{3}$ Bank for International Settlements (1999), p.23.
} 
A second objective of the study is to assess if the use of alternative portfolio models provides significantly different results with respect to optimal bank portfolios. Specifically, we use two portfolio optimisation models: the Markowitz Modern Portfolio Theory (MPT) covariance model and the Elton, Gruber, Padberg (EGP) reward-tovariability model. The reason for using the EGP model is that it provides portfolios with higher variances and lower returns (Levy and Sarnat 1984) and as also been found to be a good forecaster of future investment performance than MPT.For purposes of comparison, we also construct an equally weighted portfolio.

Nawrocki (2000) outlines a number of statistical problems with the use of traditional portfolio optimisers that perform asset allocation and portfolio allocation functions. First, securities with extreme values for returns and variances will be overweighted or underweighted in the portfolio - securities with large returns and low variances will be overweighted while securities with low returns and high variances will be underweighted. Under this scenario the likelihood of making estimation errors is high. Second, small changes in inputs such as mean returns can cause large changes in optimal asset weightings. As investors changes their estimates for risk and return over time, optimal weights become excessively unstable. Third, estimation errors in traditional portfolio optimisers prevent the determination of a single set of estimated returns and variances. This means that alternative solutions that are non-optimal may be returned. Elton, Gruber and Padberg (1976) developed a successful portfolio heuristic by using a single average correlation coefficient. They demonstrate that this approach will provide stable portfolio allocations and more diversification than a standard optimiser. Our study uses both an EGP optimisation algorithm and a MPT mean/variance optimisation algorithm to estimate the optimal portfolio allocations of bank stocks for the two periods under consideration.

The 26 countries whose bank stocks are included in the study are listed in Table 1.

Table 1: Countries Included in the Study

\begin{tabular}{|l|l|l|}
\hline Australia & Italy & Singapore \\
\hline Belgium & Japan & South Africa \\
\hline Canada & Luxemburg & Spain \\
\hline Chile & Malaysia & Switzerland \\
\hline Denmark & Mexico & Thailand \\
\hline Germany & Netherlands & Taiwan \\
\hline Greece & Norway & United Kingdom \\
\hline Hong Kong & Philippines & United States \\
\hline India & Portugal & \\
\hline
\end{tabular}

We use the monthly bank industry group index data reported for all these markets by Datastream.

\section{Results}

Tables 2 and 3 summarise our results of the 1992-1996 period. With respect to the results given in local currencies the dominance of the Asian stocks in the optimum portfolios is noticeable. The optimum portfolios exhibit significant skewness and kurtosis Earlier we discussed our expectation of lower volatility in bank stock returns in light on the capital charge for risky assets being implemented by banks during this period. In the \$USdenominated results the ECP portfolio yields higher returns than the MPT portfolio, but a lower level of risk does not compensate these returns. The equally weighted portfolio demonstrates fat tails and low returns to both variance and semi-variance, compared to the optimal portfolios constructed. The returns to beta for the optimal portfolios are significantly higher than for the equally weighted portfolio. The ECP portfolio and the equally weighted portfolio demonstrate significant positive skewness at two standard deviations, which offers an attractive protection against downside risk. 
The local currencies portfolio overweights the Asian stocks (Philippines, Hong Kong and Malaysia) by comparison with the \$US portfolios but interestingly even in the latter bank stocks from two Asian countries(Hong Kong and Malaysia) are included in the optimal ECP portfolio for this period. This lends support to our hypothesis that investors in bank stocks in the Asian region were 'comforted' by the introduction of risk-based capital standards to banks in the region, and that these investors did not anticipate that higher returns from banks in the region were being achieved with higher risk loan categories. Weston and Ford (2002) discuss how despite the introduction of risk-based capital standards, riskier assets were not being appropriately measured due to accounting standards, provisioning policies and loan classifications in the region.

When the countries were ranked by standard deviation, eight of the twenty-six were found to have high standard deviations (greater than 9\%). We investigated whether eliminating these banking sector stocks had an influence on the performance of the optimal portfolio .In fact taking these out only resulted in less diversified portfolios and did not make a significant difference to the results.

Tables 4 and 5 summarise our results for the second period of the study, which incorporates the Asian financial crisis, subsequent recovery and banking system restructures in the region. The optimal portfolios under both MPT and EGP approaches are significantly changed when compared to the first period of the study. As expected, Asian banking sector stocks drop out of the optimal portfolios. However, more surprising is that banking stocks in the United States and the United Kingdom also drop out of the optimal portfolios. While the lower performing banking stocks from the Asian region drop out, the period is still characterised, somewhat counterintuitively, by higher risk stocks that are not being compensated for by higher returns. That is, risk-adjusted returns have dropped significantly during the second period of the study.

Despite the crisis in the Asian region and expected lower-risk taking on the part of banks in the restructuring and recovery period, the terminal wealth is higher for the equally weighted portfolio that includes all of the Asian countries listed in Table 1. This suggests that a genuinely diversified portfolio is achieved when using all countries in the construction of the portfolio. Thus despite a convergence of bank capital adequacy standards for risk taking, there appears still to be a considerable amount of low or negative correlations among bank stock returns. Further, the removal of highest risk stocks in the first period from the portfolio constructed in the second period results in a significant decline in investment terminal wealth and returns to variance and semi-variance do not improve. This is an important result. It suggests that high risk-banking sector stocks are required to maintain stable returns to a global banking stock portfolio. The shift in portfolio focus between the two periods in the study appears to confirm that global investors in banking stocks require a full range of countries in their portfolios to maintain reasonable returns over time. In fact, the equally weighted portfolio performs so well in the second period that a realistic portfolio strategy for the full period 1992-2001, which includes the Asian financial crisis, might well have been holding an equally weighted portfolio.

\section{Conclusions}

We have investigated the optimal composition of global local currency and US dollar-based portfolios of bank stocks during the period January 1992 to June 2001 using both the MPT and EGP approaches to portfolio optimisation. The period was divided into the post-Basel pre-Asian crisis years of 1992 to 1996 and the Asian crisis and recovery period from 1997 to June 2001.

Our conclusions make three distinct contributions. First, we find that the ECP and average correlation portfolios yield higher returns than the MPT portfolios, but these are not compensated for on the risk side. Second, we find that for the first period of the study, investors in Asian bank stocks achieved higher returns unaware of the substantial credit risks building in the books of Asian books. This is despite the introduction of risk-adjusted capital adequacy standards for banks, because it is apparent that accounting practices and provisioning policies in the region were misaligned with the new capital standard. Fundamentally, banks in the region were able to engage in regulatory arbitrage. Third, we find that for the entire period 1992-2001, a genuinely diversified portfolio of global bank stocks should not have eliminated higher-risk stocks because these stocks are required to achieve stable returns. Indeed, the 
terminal wealth on an equally weighted portfolio outperforms the portfolios on which higher-risk banks stocks are eliminated.

Our last finding is important because it suggests that investors in banking sector stocks should not panic at the sign of a crisis, but rather, be aware that a truly diversified bank sector portfolio representing all of the 26 countries listed in Table 1 will achieve reasonable and stable returns regardless of the cycle. $\mathbb{L}$

Table 2: Local Currencies: Optimal Portfolios: 1/1992 - 12/1996

\begin{tabular}{|c|c|c|c|}
\hline & MPT portfolio & EGP portfolio & Equal weight \\
\hline Annualised return (\%) & 37.8704 & 42.4870 & 22.4217 \\
\hline Monthly return (\%) & 2.7123 & 2.9946 & 1.7001 \\
\hline Terminal wealth & 5.1273 & 5.9524 & 2.7038 \\
\hline Standard deviation of returns (\%) & 3.6607 & 5.9998 & 4.0983 \\
\hline Semi-deviation of returns $(\%)$ & 1.2819 & 2.1560 & 1.8937 \\
\hline Skewness & 0.6665 & 1.4078 & 0.6995 \\
\hline Kurtosis & 5.8975 & 8.0786 & 5.0255 \\
\hline Beta & 0.2745 & 0.3469 & 0.2480 \\
\hline Probability $($ return < 0\%) $(\%)$ & 0.2294 & 0.3088 & 0.3157 \\
\hline Return/variance (\%) & 0.6736 & 0.4580 & 0.3547 \\
\hline Return/semi-variance (\%) & 1.9230 & 1.2746 & 0.7676 \\
\hline Return/beta (\%) & 8.9833 & 7.9215 & 3.8671 \\
\hline Portfolio utility & 2.5783 & 2.6347 & 1.5323 \\
\hline \multirow[t]{4}{*}{ Portfolio composition } & Philippines & Philippines & \\
\hline & South Africa & Hong Kong & \\
\hline & Luxemburg & Malaysia & \\
\hline & & Luxemburg & \\
\hline
\end{tabular}

Table 3: Optimal Portfolios \$US: 1/1992 - 12/1996

\begin{tabular}{|c|c|c|c|}
\hline & MPT portfolio & EGP portfolio & Equal weight \\
\hline Annualised return $(\%)$ & 28.3497 & 29.0775 & 20.3336 \\
\hline Monthly return (\%) & 2.1017 & 2.1498 & 1.5544 \\
\hline Terminal wealth & 3.6321 & 3.6779 & 2.4845 \\
\hline Standard deviation of returns $(\%)$ & 2.3459 & 2.7810 & 3.7431 \\
\hline Semi-deviation of returns $(\%)$ & 0.6524 & 0.9688 & 1.7233 \\
\hline Skewness & 0.3073 & 0.3699 & 0.7038 \\
\hline Kurtosis & 3.2248 & 3.7706 & 5.1103 \\
\hline Beta & 0.2192 & 0.2966 & 0.3386 \\
\hline Probability (return < 0\%) (\%) & 18.5200 & 0.2197 & 0.2454 \\
\hline Return/variance (\%) & 0.7908 & 0.6844 & 0.3485 \\
\hline Return/semi-variance (\%) & 2.8435 & 1.9645 & 0.7589 \\
\hline Return/beta (\%) & 8.4628 & 6.4175 & 3.8523 \\
\hline Portfolio utility & 2.0467 & 2.0725 & 1.4143 \\
\hline \multirow[t]{8}{*}{ Portfolio composition } & Belgium & Belgium & \\
\hline & Chile & Hong Kong & \\
\hline & Luxemburg & Malaysia & \\
\hline & Netherlands & Luxemburg & \\
\hline & Philippines & Netherlands & \\
\hline & South Africa & Philippines & \\
\hline & US & UK & \\
\hline & & $15 \%$ & \\
\hline
\end{tabular}


Table 4: Optimal Portfolios Local Currencies: 1/1997 - 6/2001

\begin{tabular}{|c|c|c|c|}
\hline & MPT portfolio & EGP portfolio & Equal weight \\
\hline Annualised return $(\%)$ & 24.1639 & 23.8515 & 17.3802 \\
\hline Monthly return (\%) & 1.8200 & 1.7986 & 1.3444 \\
\hline Terminal wealth & 2.7815 & 2.7190 & 2.0567 \\
\hline Standard deviation of returns $(\%)$ & 3.6919 & 3.7085 & 5.4863 \\
\hline Semi-deviation of returns $(\%)$ & 1.9713 & 2.0118 & 3.8277 \\
\hline Skewness & -0.4145 & -0.4709 & -1.1480 \\
\hline Kurtosis & 3.3256 & 3.2975 & 0.8082 \\
\hline Beta & 0.3663 & 0.3799 & 0.6714 \\
\hline Probability (return < 0\%) $(\%)$ & $31.10 \%$ & $31.38 \%$ & .4328 \\
\hline Return/variance (\%) & 0.4262 & 0.4185 & 0.1263 \\
\hline Return/semi-variance (\%) & 0.7981 & 0.7714 & 0.2868 \\
\hline Return/beta $(\%)$ & 4.2953 & 4.0853 & 0.8522 \\
\hline Portfolio utility & 1.6837 & 1.6611 & 1.0434 \\
\hline \multirow[t]{6}{*}{ Portfolio composition } & Australia & Australia & \\
\hline & Denmark & Denmark & \\
\hline & Greece & Italy & \\
\hline & India & Luxemburg & \\
\hline & Luxemburg & Portugal & \\
\hline & Norway & Spain & \\
\hline
\end{tabular}

Table 5: Optimal Portfolios \$US: 1/1997 - 6/2001

\begin{tabular}{|c|c|c|c|}
\hline & MPT portfolio & EGP portfolio & Equal weight \\
\hline Annualised return (\%) & 23.6418 & 24.3626 & 13.4852 \\
\hline Monthly return (\%) & 1.7842 & 1.8335 & 1.0598 \\
\hline Terminal wealth & 3.1353 & 3.2306 & 3.2911 \\
\hline Standard deviation of returns $(\%)$ & 5.8050 & 6.0991 & 4.6050 \\
\hline Semi-deviation of returns $(\%)$ & 3.5293 & 3.6341 & 2.9533 \\
\hline Skewness & -0.7239 & -0.5430 & -0.3761 \\
\hline Kurtosis & 5.1813 & 5.2263 & 6.1734 \\
\hline Beta & 0.6754 & 0.6892 & 0.6714 \\
\hline Probability (return <0\%) $(\%)$ & 37.9300 & 38.1900 & 0.4773 \\
\hline Return/variance (\%) & 0.2649 & 0.2602 & 0.1759 \\
\hline Return/semi-variance (\%) & 0.4357 & 0.4367 & 0.2753 \\
\hline Return/beta (\%) & 2.2767 & 2.3024 & 1.2061 \\
\hline Portfolio utility & 1.4472 & 1.4615 & 0.8477 \\
\hline \multirow[t]{5}{*}{ Portfolio composition } & Denmark & Denmark & \\
\hline & Greece & Greece & \\
\hline & Ireland & Italy & \\
\hline & Italy & Mexico & \\
\hline & Mexico & & \\
\hline
\end{tabular}




\section{References}

1. Bank for International Settlements (1988), "International Convergence of Capital Measurement and Capital Standards", Basel Committee, Publication No.4, July.

2. Bank for International Settlements (1999), "Capital Requirements and Bank Behaviour: The Impact of the Basle Accord", Basle Committee on Banking Supervision, Working Paper No.1, April.

3. Calem, P. and Rob, R., (1999), "The Impact of Capital-Based Regulation on Bank Risk-Taking", Journal of Financial Intermediation, 8, 317-352.

4. de Athayde, G. (2001), "Building a Mean-Downside Risk Portfolio Frontier", in Sortino, F and S. Satchell, Managing Downside Risk in Financial Markets: Theory, Practice and Implementation, Butterworth Heinemann, Oxford.

5. Elton, E., Gruber, M. and M. Padberg (1976), "Simple Criteria for Optimal Portfolio Selection", Journal of Finance, 31(5), 1341-1357.

6. Furfine, C. (2000), "Evidence on the Response of US Banks to Changes in Capital Requirements", Bank for International Settlements, Working Paper No. 88, June.

7. Furlong, F. and Keeley, M. (1989), "Capital Regulation and Bank Risk Taking: A Note", Journal of Banking and Finance, 13, 883-891.

8. Gennotte, G. and Pyle, D. (1991), "Capital Controls and Bank Risk", Journal of Banking and Finance, 15, 805-824.

9. Harlow, W., (1991), "Asset Allocation in a Downside-Risk Framework", Financial Analysts Journal, September/October, 28-40.

10. Kim, D. and Santomero, A. (1988), "Risk in Banking and Capital Regulation", Journal of Finance, 43, 1219-1233.

11. Koehn, M. and Santomero, A. (1980), "Regulation of Bank Capital and Portfolio Risk", Journal of Finance, 35, 1235-1250.

12. Lucas, A. \& P. Klaassen (1998), "Extreme Returns, Downside Risk and Optimal Asset Allocation", The Journal of Portfolio Management, Fall, 73-78.

13. Nawrocki, D., (1996), "Portfolio Analysis with a Large Universe of Assets", Applied Economics, 28, 11911198.

14. Nawrocki, D., (2000), "Portfolio Optimization, Heuristics and the 'Butterfly Effect", Journal of Financial Planning, February, 68-78.

15. Olsen, R. (1998), "Behavioural Finance and its Implications for Stock Price Volatility", Financial Analysts Journal, March.

16. Padoa-Schioppa, T. (1996), "Address to the Conference", Speech given at the Ninth International Conference of Banking Supervisors, Stockholm, June.

17. Passmore, W and Sharpe, S. (1994), "Optimal Bank Portfolios and the Credit Crunch," Finance and Economics Discussion Series 94-19, Federal Reserve Board of Governors.

18. Rom, B. \& K. Ferguson, (1994), "Post-Modern Portfolio Theory Comes of Age', The Journal of Investing, Fall, 11-17.

19. Sheldon, G. (1996), "Capital Adequacy Rules and Risk-Seeking Behaviour of Banks: A Firm-Level Analysis", Swiss Journal of Economics and Statistics, 132, 709-734.

20. Sortino, F. \& L. Price (1994), "Performance Measurement in a Downside Risk Framework", The Journal of Investing, Fall, 59-64.

21. Thakor, A. (1996), "Capital Requirements, Monetary Policy and Aggregate Bank Lending: Theory and Empirical Evidence", Journal of Finance, 51, 279-324.

22. Weston, R. and G. Ford, (2002), "Bank Risk and Return in the Asia Pacific Region: A Cross Country Analysis", Paper presented at the Global Finance Association Conference, Beijing. 